\title{
Reflective practice and the development of competencies for health promotion in nurses' training*
}

\author{
Prática reflexiva e o desenvolvimento de competências para a \\ promoção da saúde na formação do enfermeiro \\ Práctica reflexiva y el desarrollo de competencias para la \\ promoción de la salud en la formación del enfermero
}

Luciana Nettoํㅜ, Kênia Lara Silva²

How to cite this article:

Netto L, Silva KL. Reflective practice and the development of competencies for health promotion in nurses' training. Rev Esc Enferm USP. 2018;52:e03383. DOI: http://dx.doi.org/10.1590/S1980-220X2017034303383

*Extracted from thesis: "Desenvolvimento de competências para a promoção da saúde na formação do enfermeiro", Escola de Enfermagem, Universidade Federal de Minas Gerais, 2016.

${ }^{1}$ Universidade Federal de São João del-Rei, Campus Centro-Oeste, Divinópolis, MG, Brazil

${ }^{2}$ Universidade Federal de Minas Gerais, Escola de Enfermagem, Departamento de Enfermagem Aplicada, Belo Horizonte, MG, Brazil.

\begin{abstract}
Objective: To analyze the insertion in reflective professional practice as a strategy for the development of competencies for health promotion in nurses' training. Method: Case study, qualitative approach anchored in the theoretical-methodological framework of the Marxist dialectic. Data were obtained from documents, interviews with graduated students and focus groups with teachers from a nursing higher education institution located in the state of Minas Gerais, Brazil. Data were examined by critical discourse analysis. Results: The most favorable contexts to reflective practice in the development of competencies for health promotion involve the practice of teaching-service-community integration, teacher-student interaction and teamwork. The discourse of early insertion is hegemonically constructed as a social practice of the study scenario. Conclusion: The characteristics of the curricular proposal of the study scenario favor the 'learning to do' mediated by experience and reflexivity by mobilizing the development of competencies for health promotion. In addition to insertion, students' immersion in the reality of services generates experiences in a reflective-critical process.
\end{abstract}

\section{DESCRIPTORS}

Education, Nursing; Health Promotion; Competence-Based Education; Curriculum.

\section{Corresponding author:}

Luciana Netto

Universidade Federal de São João

del-Rei - Campus Centro-Oeste

Rua Sebastião Gonçalves Coelho, 400, Sala 301.4 Bloco D 


\section{INTRODUCTION}

Health promotion represents a strategy for the change of techno-assistance models, since as a paradigm, it conceives health from a positive and expanded vision that is understood as a way of life, and not an objective to be achieved. As a policy, it implies a close articulation between State and society for constructing actions that enable individuals and groups to identify aspirations, satisfy needs and favorably modify the environment ${ }^{(1)}$.

Health promotion as a new way of thinking and doing health enables the confrontation of multiple problems affecting human populations and their environment ${ }^{(1)}$. However, the preparation of professionals must be expanded in order to act in health promotion with effective actions, and this process involves the development of competencies ${ }^{(2)}$.

The theme of competencies in health promotion has been discussed in international contexts in recent years. In Brazil, there are few studies indicating the adequacy and specificities of the competencies for health promotion in the national scenario or teaching strategies for the development of these competencies ${ }^{(2)}$.

The debate about the change in health professionals' training is justified by the need to break the limits imposed by technical rationalism and the fragmentation of knowledge that are conditioned hegemonically by the Cartesian paradigm. Thus, the change in education and teaching has stimulated the creation of pedagogical proposals by incorporating new technologies and active teaching methodologies ${ }^{(3)}$.

Emphasis is given to the need to train critical and reflective people and professionals with a kaleidoscopic view of the world $^{(4)}$. In this sense, reflective practice (reflective practicum) and learning to 'do reflectively' are themes of our time. To this end, professional training must provide the interaction between theory and practice, guided by reflective teaching based on the reflection-in-action process. That is, the teaching in which learning is privileged by doing, and the ability to reflect is stimulated by teacher-student interaction in different practical situations ${ }^{(5)}$.

The excess of information prevents professionals from reflecting critically on their performance and makes them lose important learning opportunities ${ }^{(5-6)}$. In the teachinglearning process, in turn, a routine and repetitive practice generates students' fatigue and disinterest ${ }^{(7)}$. This is because


they are no longer interested in the whole, but only in the part under dominion that is taught excessively to them ${ }^{(5-6)}$.

The over-specialization in training is as problematic as lack of knowledge in certain areas. This seems to be the reality when it comes to professional training and formation in the area of health promotion, which is still considered incipient in Brazil ${ }^{(2,8-9)}$.

The core competencies to act assertively in health promotion were defined by the pan-European project CompHP (Developing Competencies and Professional Standards for Health Promotion Capacity Building in Europe $)^{(10)}$ of 2009, which included a set of nine areas of competence, namely: Enable Change, Health Advocacy, Mediation through partners, Communication, Leadership, Needs assessment, Planning, Implementation, Evaluation and Research. The development of these competencies should be guided by ethical values and knowledge in health promotion ${ }^{(10)}$.

The essential competencies for acting in health promotion cannot be apprehended in parts with pedagogical practices that only recommend classroom activities with readings and demonstrations. Its central aspect, the whole, must be learned in an integrated way, guided and instructed by teachers in reflective teaching with pedagogical practices that emphasize the critical action-reflection-action movement for developing professional skills ${ }^{(3)}$.

In spite of the emphasis on practical-reflexive teaching, the following questions remain to be answered: Is it possible to teach competencies for health promotion from reflective practice? What is the best way to teach competencies for health promotion through reflective practice? At what point in the curriculum should practical-reflective teaching be introduced?

Curricular proposals emphasizing early insertion and immersion in professional practice may favor the articulation of theory with practice, and advance in the development of competencies for acting in health promotion. This is because intense and constant contact with reality allows that professionals produce knowledge based on their work practice. This is a principle of reflective practice defined as the 'art of intrinsic growth', which is put into practice by means of reflection with the purpose of finding a logical solution for real problems ${ }^{(5)}$.

In face of this problematic, the aim of this study is to analyze the insertion in reflective professional practice as a strategy for developing competencies for health promotion in nurses' training.

\section{METHOD}

\section{TYPE OF STUDY}

This is a qualitative case study anchored in the theoretical-methodological framework of the Marxist dialectic ${ }^{(11)}$.

\section{SCENARIO}

The methodological course of the study was organized in two phases, namely: analysis of the Course Pedagogical Project $(\mathrm{CPP})^{(12)}$, and in-depth analysis of the discourse of graduates and teachers of a Nursing higher education public institution located in a medium-sized municipality in the interior of the state of Minas Gerais, Brazil. Besides graduation in Nursing, the institution also offers Medicine, Pharmacy and Biochemistry courses.

The course was created in 2008 and 40 places are available each semester (term). The curricular contents of the CPP are organized helically in nine terms and 4,081 hours. The disciplines are called curricular units, classes are given in semester cycles of 18 weeks and last the whole day (daytime course). The course structure has six curricular units that progressively evolve until the seventh term and ends with two terms of supervised internship and preparation of the course final monography. Students' approach to the practical context of health begins from the first term of the course through 
the Practice of Teaching-Service-Community Integration (Portuguese acronym: PIESC) $)^{(12)}$.

The exploratory analysis of the $\mathrm{CPP}^{(12)}$ was performed from a script by taking the domains or attributes of competencies as axes ${ }^{(10)}$.

\section{Data collection}

Interviews (I) focused on competencies were conducted with ten out of the 57 nurses who graduated from the course. They were included after their response to the invitation to participate in the study, which was sent by e-mail at the same time for all individuals. In cases of positive responses, was made contact to schedule individual interviews according to participants' availability. The interview was based on the following inquiry: 'describe a health promotion action that you have taken responsibility for performing and indicate how Nursing training prepared you for the action'. The subjects of this sample had finished the course one or two years earlier and were inserted in the following areas of the professional market: primary care (four), hospital (four), urgent care (two) and project (one). Others were in the process of continuing education in the modalities of residence (four) and masters' studies (four). Two graduates were not in the labor market.

In order to guarantee the depth and holistic character necessary to the case study, were performed two focus groups (FG) with teachers from the Institution. For the constitution of the focus group, were invited all teachers involved in the academic training process of nurses. Fifteen out of the 45 teachers participated in the discussions, of which 11 were women and four men. Twelve of them were nurses and there were representatives of all curricular units and course periods. The average working time in the institution of participating teachers was 3.7 years.

Three observers followed the focus groups that had a total duration of four hours, seven minutes and 19 seconds. The discussion had the following guiding question: 'What strategies are used to approach the competencies for health promotion in nurses' academic training in this institution?'. A summary of the areas of competencies for health promotion was made available to participants.

The second half of 2014 was the data collection period, in which elements of oral registry were maintained, and subsequently, was performed Critical Discourse Analysis (CDA) ${ }^{(13)}$.

\section{ANALYSIS AND TREATMENT OF DATA}

The webQDA software was used to score the competencies for health promotion, facilitate the consolidation of the large volume of empirical material, management of all data to be analyzed, and support the qualitative data analysis in a collaborative environment ${ }^{(14)}$. The software was used in the analysis of all data from the consolidation of the corpus in order to facilitate the creation of categories of analysis and interpretation of empirical data.

The communication of the study results was in accordance with the guidelines for reports of qualitative research projects using interviews and focus groups available in the COREQ (consolidated criteria for reporting qualitative research $)^{(15)}$.

\section{ETHICAL ASPECTS}

The research project that originated this study was approved under number 694.248 by the Research Ethics Committee of the Federal University of Minas Gerais in accordance with Resolution 466/2012 of the National Health Council. The anonymity of study participants has been guaranteed. In order to avoid identification, each subject was coded as I, and each focus group was coded as FG followed by sequential numbering. The markers " / " are part of the transcription convention adopted and refer to the intonation, emphasis, pauses and variations in the pitch and rhythm of the speech.

\section{RESULTS}

The findings reveal the most favorable contexts to reflective practice for the development of competencies for health promotion are those including teaching-service-community integration, teacher-student interaction and teamwork.

Teacher-student interaction is understood in the analysis matrixes of discourses as the reciprocal involvement that occurs between teachers and students committed to working together, and the action of one of them causes a reaction of the other (or others), and is an element of reflexivity in the development of competencies for health promotion. The findings indicate that interaction has the potential to produce reflection on knowledge and practice in health promotion by generating learning. In this sense, the statements indicate the teacher mobilizes students to work with the promotion by constituting the link with the reality where actions will be developed.

Another teacher who mobilized to work with (...) with the promotion. (...) I guess in internship programs, there was always/there was always a/ bond focused on/ something related to the promotion, in curricular internships, right? That we did at university. I think there was always something focused on the promotion (I 10).

That's what I wanted to say (...) 'causel I think the teacher (...) he's the main actor, I guess because he's the one doing it, (...) the link with the student, he's gonna create the bond with professionals there in the field, also with the community, also in the field, or in the hospital, (...) then MY UNDERSTANDING is (...), and when we talk about (quality)/is/ health promotion, (...), just like the (colleague) said, not only theory itself, practices, but values, / psychosocial aspects interfere greatly, (...), because depending on a culture, in a community, we will have to act in one way or another, and we really perceive that in the PIESC, (...) (FG 1).

Specifically, reflection on health promotion actions stands out in the training process. It is driven by aspects linked to practice, doing, and intertextual action from the beginning of the course. In the reports, are identified competencies related to domains of enable change, implementation of actions, and knowledge and ethical values guiding the practice of health promotion.

In order that nursing education can be apprehended in its entirety under the 'total social fact' approach, is needed knowledge that dynamically articulates the social, psychological and biological dimensions. This implies a teaching developed through integrated practices that incorporate technical and popular 
knowledge, and see men in their context, which extrapolates the health sector and challenges us to seek intersectoriality by showing students they are subjects of the process within their conditions and reality. They must participate and cease to be subordinate to the learning process (CPP, p. 16) $)^{(12)}$.

$I$ acquired the learning through experience in the field and the teachings of masters who participated in my graduation. (...) We had several, mainly, it is/ we had psychosocial bases with several teachers and they taught us/ us, (pauses to elaborate the answer), they guided us in this part of how important health promotion is, not only that part of / of you healing, of the healing, it is you promoting health in order to avoid having to enter intol in healing action. We had this in mind throughout all graduation. (...) (I 2).

In several moments, I have developed practices with users on how to prevent diseases through meetings in which we guide these users on healthy practices, and also guide them regarding self-care when a disease is already established, in order that they have a better life expectancy, even with diseases already established (I 2).

Yes, I think, in the matter of our curriculum, we are always doing this in several/ several subjects (...). In various activities, whether in the health of women, children, in the administrative matter. So, I think our curriculum is very rich in this issue of encouraging people to do these/ promotion projects (I 6).

The main mark of the course in the development of competencies for health promotion is students' insertion in the reality of services and the community since initial terms through the curricular unit denominated Practice of Teaching-Service-Community Integration (PIESC Prática de Integração Ensino-Serviço-Comunidade). This curricular unit happens from the $1^{\text {st }}$ to the $7^{\text {th }}$ term. Teachers consider it a stimulator of the development of competencies for health promotion because it demands mainly the application of domains of knowledge, ethical values, leadership and implementation of actions.

Our experiences, they/are from the PIESC.I I think: where are students more conducive to developing these competencies?/ Where they materialize everything they are learning or living. This is our professional practice/ We materialize in our PRACTICE / what we have been receiving as an instrument,/ whether theoreticallor practical. In university, the materialization of these practices/ in my view, it/ is very concentrated in the PIESC, (...). It is the moment of integration, the moment of clinical reasoning, the time for management, it is time to lead, it is time to be led, (...) So it is/ I think in our curriculum, we are making adjustments in order to achieve these competencies/(FG 1).

In participants' speeches, there is a clear confusion between the following terms: health promotion and disease prevention.

We see this way/like in the PIESCII, we work with healthy food a lot in the PIESC III/ sexuality, contraceptive methods, / only that/ us in PIESC II and III do not work so much with alcohol and drug prevention,/smoking, do we? (FG 1).

Well, I remember in the undergraduate course, practices of health promotion developed were related to extension programs (Portuguese acronym: PET). (...) Yes/ we carried out campaigns of humm/ prevention of breast and uterine cervix cancer/ humm/ in the central region (...) and also in health units (...) (I 1).
Health education, right? It was/ (...) in internships/ during internships, we promoted a lot off (...) (hesitation) lectures really, even for patients in health units/ and taught the issue of diet, diabetes mellitus/ hypertension, you know?/Yes/ stimulated healthy life habits, all this, we did this type of practice./ At schools too, there was an extension project in which/ we went to schools and taught children that/ hygiene habits, you know? For the prevention of/ of diarrhea diseases and/ you know? That involves hygiene, really. These were common practices for health education (I 7).

Although they can contribute to the development of competencies, the discourses reveal the conceptual imprecision about health promotion. Sometimes, the biological perspective and the preventive character prevail, which are linked to practices without revealing the current political dimension in the field. Nevertheless, the findings indicate that extension programs (Portuguese acronym: PET) and clinical teaching (PIESC) allow the materialization of reflexivity by confronting the theoretical and the practical, and generating reflection on the action when students experience the reality of health services in contact with the population and their context of life.

(...) In the PIESC III we will work the/ child's consultation/ work in the vaccination room and,/ it's just that students forget. / EVERY day I have to remind them/ that health promotion actions, they always need to be/ INTHE CONTEXT, (...) So, if a child comes, we already have to worry about that little baby, / who is going to start walking, (...) with what he is going to play in order to promote his health./Then, students, when they provide guidance, they already have to think about it.I And I DEMAND this EVERY DAY from them, because an adult will be healthy if he/she starts with health promotion early (FG 2).

So, I think the PIESC/ not only in the 1st term, but/ in the others, I I speak of the 1st term because it is more my EXPERIENCE, in the 1st term. It is when we take students, INSERT students in the field, / from the beginning, and of course, it is planned, where are we going to intervene, what are we going to do,/I can see the fulfillment of all those ninel COMPETENCIES there, okay? (FG 2).

The competencies for health promotion are developed in the process of bringing students closer to services and the community. However, discourses, as part of a social practice, reveal contradictions. Among them, there is teachers' appropriation of the curriculum in their own way. In this sense, the 'sacred' metaphor used to characterize the PIESC indicates that everyone respects its offer, even if they do it in their own way by disfiguring it with the allocation of specific spaces for discussing themes chosen by teachers from their specialties. Discourses also point to the debate about learning opportunities that overcome 'over-information' and focus on the 'essential' that in itself is too dense.

(...) because today, the PIESC, for us, it has becomel something institutionalized/within our curriculum. (...) the PIESC is there in the curriculum / and,/ from the 1st to the 7 th term it/ it/ it's done./Nobody, / in no term it is LACKING./Surely, there are some differentiations, but / it has BECOME something kind of SACRED / in our curriculum, like (...) (coughs) the PIESC./Now, / is / I still think this thing of us going there and 
giving a theoretical lecture, / it passes / what you were putting (points to the colleague)/like / three months / I go there and give another little class / then, another two months./ And we use THE SAME methodologies, (...) This is something in which I think we need to advance / in order TO reach / THESE/ competencies here /(FG 2).

One thing that/'cause, from what you're saying, we need the wholeness. (...) And I see that we have a TREMENDOUS need of, that it took us 10 years, 15 years, (...) we want students to LEARN, and sometimes in a term, you know? / (laughs) (...). What I learned in a WHOLE LIFE, I want them to learn in three weeks./Then, I mean, this is ANOTHER/ (at that moment, another teacher signals demonstrating agreement with the participant's comment)/another complication, is that fear we have: Wow, if I don't teach this, where will they learn it? How will they give vaccine, if I do not teach this?/ We want to teach everything, we DISORIENTATE the student, you know?! (...). So, they will conquer throughout, but no, we reverse, we want to teach everything we've learned, that we've built in 10, 15 years/you know/in a graduation course. / So, we/ I guess this should be mentioned, I think it's better if we teach the essentials, (...)/And the essential is too dense, (...)/That essential, it's too dense, isn't it? (...) (FG 1).

For participants, the PIESC allows the early insertion in the field, since it happens from the beginning of the course. This discourse is textually constructed in the recommendations of the Course Pedagogical Project ${ }^{(12)}$ and incorporated as social practice by teachers and graduates.

The recognition of the difference between going to field (insertion) and being in the field (immersion) was identified as something sporadic and continuous, respectively. Thus, simply "putting students before the populations' health needs" is not enough, and demonstrates the necessity to stay in the field. Immersion requires presence, permanence and continuity, which appear in the reports in expressions such as "being in service", "really experiencing", "demands time and demands contact" that modulate discourse. Therefore, is revealed the commitment of contact with reality as a condition for the development of competencies for health promotion.

The insertion of nursing students will occur from their first academic year, in the social and health reality of the municipality. The purpose is to place them in the face of populations' bealth needs in order that they take responsibility for them during the process by seeking to intervene systematically (CPP, p. 10) $)^{(12)}$.

(...) within what the (colleague) considered (...) When he says/ his continuity, (...) in the PIESC, the time you stay with students, / to have condition of giving feedback/for these students, made me think of the ninel in the nine competencies./ I think where there is a PIESC, that if/ students come and stay with you two days, / then go to another one to stay one day, / then go to another to stay two days, / it is hard that you, as a professor/ and the student as a student will/ GET_(at this time another professor demonstrates agreement with the participant's comment)/ developing those competencies here./ (...) Now, / is/ developing THESE competencies/ is in this/ in a PIESC modality different from what the (colleague) is mentioning,/ where students stay one day, two days, I find it very difficult to achieve this from here./ Because it requires time, feedback, requires contact with/ with/ with users, requires contact with the work team, requires greater contact with THAT teacher/AND THAT stu$\operatorname{dent}$ (FG 2).

(...) Well, FOR SURE, for sure, mainly because students' insertion in the field since the PIESC I/ already makes it a lot easier, because students have a very comprehensive vision of thel of the service; it is very different if you are only in the classroom, studying about the health system, but not knowing the reality; and going to the field later, more in the final terms. (...) Now, if you are in the service and really experiences along with the population what are the impediments, the facilitators for treatment follow-up, (...) this is another/ a very important addition (I 9).

Teachers affirm that besides going to the field of practice early, it is necessary to strengthen the bond with the reality experienced in being, and by the continuity of contact with care practices, the population and the team. Experiencing and understanding the social reality is a sine qua non for promoting the population's health.

(...) students/yes/they, / since the 1st term, they analyze the territory, know the environment,/ know the health situations, the iniquities this population lives and, from this knowledge, they will CHOOSE a family, and within that family they will try to propose changes there, / plan the assistance to this family, yes/ BRING this family to recognize their own problem and try to empower/ empower this family so that they can/ACTUALLY change or adhere to this treatment./ We use health education activity, communication, transmission of information, / or, at some moments, the APPROPRIATION of information, / so that the family CHANGE their own reality./ Students make/ that diagnosis, (...) of that area. They stay the whole semester,/FROM the environment, family, until reaching the individual./ We have managed to do that. There are a number of actions that we implement, / is/ within that family. (...) In other words, it is not only a specific action that students go there, plan an intervention/ and work SPECIFICALLY, no./We try/ to give continuity (at this moment another teacher acquiesces in agreement with the participant's statement) (FG 1).

And the second experience, (...) is an extension project, (...) that we work with/ is/ the access of adolescents and the inclusion/ informational, digital, of school adolescents. I And who does ALL the mediation process with these adolescents, (...) So they go, / they access, / they prepare the dynamics/face-to-face dynamics,/ virtual dynamics, (...)./ TAKE adolescents to understand the themes of adolescence, (...) self-care, that is, / I can also see this extension program, / is/ several of these competencies, (...) to enable change,/ partnerships, in this case with the school,/ the issue of the use of technologies, / of information, communication, / the LEADERSHIP/(FG 1).

Because, for me, working with/ the student working with the population,/spending time together, dialogue, eye to eye, / that I develop in some works, you know? I think like that./Then, when you are in a discipline, in which/ you go there,/ I go today, in three weeks I give a class, in five weeks I give another, it's over.I So, I have a contact of four hours, two hours with a class, / then another broken contact. It's not that I cannot DO it, but I find it/ difficult, you know, to be more complete (FG 2). 


\section{DISCUSSION}

The results show the competencies for health promotion are developed during training in the study scenario. In particular, the domains of knowledge (which allow differentiation between promotion of curative action and guidance through lectures in an intersectoral articulation exercise, and integration of technical and popular knowledge for understanding men in their context), values (recognizing the culture), enable change (orientation for the self-care practice), leadership and implementation of health promotion actions (putting projects into practice).

In Brazil, the discussion about the model of competencies for health promotion mentioned by the CompHP is not very frequent. However, even below desirable, some domains included in it are being developed in undergraduate courses in the health area, including nursing ${ }^{(2,8)}$. This development below desirable has repercussions on the performance of graduates and on the health concept guiding professional practice in the current health system ${ }^{(8)}$.

The findings also highlight the imprecision and conceptual confusion in the content of the so-called health promotion practices developed in the training process. In this sense, at times, they refer to the paradigmatic dimension with a broader concept of health, and at other times, reveal the political-practical dimension with preventive and curative interventions on the health-disease process.

The imprecision and conceptual confusion result in the low development of competencies, which, in turn, not being stimulated, make the necessary advances difficult and culminate in a cycle of reproduction that includes ignorance about health promotion and inability to perform actions in this field. It is important to recognize that health promotion knowledge, which includes concepts, approaches and methodologies, forms the central domain of CompHP ${ }^{(10)}$. Thus, in order to overcome the cycle of reproduction of the discourse orders in the social practice under analysis, there must be a clear definition about the competencies required from professionals for the promotion of health ${ }^{(9)}$. Such a process can be stimulated and guided by the Reflexivity Theory.

A discursive practice that intersects progressive and behavioral notions of health promotion in the speeches of graduates and teachers is also analyzed. This interdiscourse is the result of the open conceptual debate in the field of health promotion that admits different perspectives. In this context, more important than demarcating the precise and immutable concept, is to recognize that health promotion is broader than prevention, but does not invalidate it by overcoming the characteristic antagonistic thinking of discussions in the area. In addition, it also requires environmental, economic, socio-cultural and legislative measures for its implementation ${ }^{(16)}$.

In this regard, the analysis of discourses reveals the reflexivity basis of the training process, in which the focus is doing, living, and practicing. Other studies also demonstrate that the most significant and learning-generating experiences in academic formation processes occur during actions that materialize in the teaching-service-community integration ${ }^{(17)}$.
For health promotion training is no different. In the study scenario, experience comes from learning 'to do by doing reflectively', which is how to acquire knowledge and develop the competencies provided in CompHP ${ }^{(10)}$.

The experience strengthens students by promoting their autonomy, self-esteem and self-confidence that are characteristics of reflexivity, since they experience and live immersed in the context of practice ${ }^{(5)}$.

Participants mention the learning 'to do by doing reflectively' in order to develop sustainable actions for health promotion as the condition reinforcing the stimulus to exercise the living, critical and reflexive thinking in the educational context. Such thinking has foundations in the valuation of different capacities, the formation of the individual quotient of emotional intelligence, in social and interpersonal skills, in professional achievement and conscious citizenship ${ }^{(4)}$.

The discourses demonstrated the practice as the scenario that favors the development of competencies for health promotion, especially since it can materialize actions/projects by revealing mainly the domains of knowledge, ethical values, leadership, communication and implementation. Continuing action in the field of practice by insertion and immersion in health services acts as a device for making learning meaningful for students. It also allows the articulation between theory and practice, and between teaching, service and community by leading to the development of competencies and consolidation of knowledge.

The result of reflective learning only becomes evident when students enter a new context and feel secure and confident to act by showing what they have learned in another situation ${ }^{(5)}$. This experience of critical, reflexive, logical, and systematic thinking is fundamental for intellectual maturation.

In the study scenario, the curricular unit named PIESC was pointed as the pedagogical proposal that emphasizes the dialectic relation of practice with theoretical construction. Moreover, it provides conditions for the development of competencies, and care, educational, administrative and investigative skills for individual and collective care. In the PIESC unit, there is a search for achieving integration with professionals, health services and the community, and strengthening of SUS (Portuguese acronym for the Brazilian Health System). This expanded vision of health and the establishment of partnerships favors the reflective practice, which facilitates the planning and implementation of health promotion actions. Thus, effective teaching-service-management-community integration favors the insertion of students in the labor world by leading them to develop a critical and reflective practice ${ }^{(3)}$.

The insertion in the field of practice is an opportunity for students' experience of the daily routine of nursing care. This is normally compulsory because it is part of the PIESC course unit. However, students' insertion in practice from the $1^{\text {st }}$ term does not guarantee in itself the integration of theory and practice and of teaching-service-community, and the development of competencies, including those of health promotion. If there is no intentionality, motivation and orientation from teachers for this purpose, this fertile ground may prove inhospitable. 
Considering that students only learn what they consider as significant, going to the practice scenario must be tied to some specific purpose, in which fulfillment of the training need must satisfy the premise of student-centered teaching. In addition, the insertion allows experimentations, but experiences are constructed in the immersion.

Nonetheless, the discourses, as part of a social practice, reveal the contradictions in this practice when questioning about the integration and permanence of the traditional model of teaching with punctual contacts. In this sense, there is a disfigurement' of the PIESC practice that should be integrative.

The discourses indicate the development of competencies for health promotion requires students' time of interaction with the field, the team and the teacher. Students' greater contact with the context, health determinants and the team is supported in other studies in the area ${ }^{(18-20)}$. Thus, teachers mention the need to keep students longer in the field of practice, especially in primary care, in order to reinforce reflexivity by empowering them to think and propose solutions for problems of the context with a view to transforming the scenario where they are inserted. To this end, it is necessary to overcome moments of experimentation and construct real experiences in the development of competencies for health promotion.

The experimentation resembles a practical class by focusing on the repetition of actions in a controlled environment, and emphasizing rigor. This practice is focused on demonstration, and restricted to saying and/or hearing what was arranged and doing it by imitation. Teaching through experimentation generates dependent, defensive, and vulnerable students. Experience, on the other hand, comes from contact with the real world and its myriad possibilities and risks, that is, learning is contextualized and becomes relevant and meaningful for students ${ }^{(5)}$.

In addition to an experiment, the competencies experienced allow that students develop the capacity to reflect on their experience. Thus, students will learn to deal in practice with situations outside the routine with the uncertainty, singularity and conflicts inherent to their daily practice by becoming responsible for their learning. This reflective practice moves away from the normative professional curriculum by opening doors to new ways of learning and teaching, in which the order of theory first, followed by practice can be reversed ${ }^{(5)}$.

The discourse of early insertion is hegemonically constructed as a social practice of the study scenario. Beyond this insertion, it is necessary to invest in students' immersion in the reality of services and determinants of health and illness of the population.

Immersion, unlike insertion, goes beyond the sporadic and punctual presence in the scenario of practice, as in cases of numerous internship programs, where students know the field of practice, but do not create bond. Immersion allows prolonged contact with social contexts and tends to provoke students' critical reflection on what happens in their surroundings by producing experiences. This reflection enables advancing in the search for logical solutions to problems of the population and favors the systematization of professional practices in health services.
In order to favor the development of competencies, there must be investment in pedagogical proposals that favor immersion, being, living and the experience, to the detriment of sporadic activities that do provoke experimentation, but punctual and transient in the field. The immersion in health practices and services enables students to have a critical and reflective perception of reality by seeking the essence of processes, their continuities and ruptures. This articulation of acquired knowledge with reality can stimulate behavioral changes in professional practices, and distance future professionals from the traditional model of health, since, in this way, one learns by doing reflectively ${ }^{(3,19,21)}$.

In nursing reality, immersion in practice fields enables moments of continuous exchange by favoring work relationships with the team, knowledge of the professional's work in its magnitude, development of competencies and care and management dimensions. That is, these are moments in which educators and students act collaboratively for the development and execution of activities by adding the dimensions of attitude, skill and knowledge that are supported by an educational praxis stimulating reflexive and active thinking ${ }^{(3)}$.

Despite the theoretical, critical and practical possibilities of the experience in the educational field, simply inserting students in the field is not enough. Although in this way, they will be exposed to experimenting the care practice, they will not to go deep enough for producing the necessary experience for a good professional practice. Immersion, as opposed to insertion, fosters a sense of belonging, a constituent element of the bond, which leads to the development of new concepts, which includes those of health promotion, based on the experience lived in the field of practice ${ }^{(6,19)}$.

The development of competencies for health promotion can be favored by immersion in a learning space that allows the stimulation of creative and cognitive potentialities directed by teachers with this intentionality in order to enable a broader view of reality and favor autonomy.

The objective and subjective conditions in nursing education should consider the involvement, interests, expectations and intentions of all those involved in the process, namely: students, teachers, professionals, community and managers.

Thus, the results indicate challenges regarding health promotion, which become evident by the inaccuracies and confusion in actions developed in/by the health services. This finding is explained by the limits of the political and paradigmatic incorporation of health promotion in training and, consequently, in professional practice.

In this direction, the development of competencies for health promotion during training can be a strategic action to change education and produce effects in services that are aligned with demands of national policies and social needs. To that end, the teaching-service-community relationship is an axis deserving discussion for expanding possibilities of putting into practice other actions that allow reflective training in contexts of professional practice.

\section{CONCLUSION}

The results demonstrate the curricular proposal of the study scenario has characteristics that favor the learning 
mediated through experience and reflexivity by mobilizing the development of competencies for health promotion.

Since health promotion is a concept and a practice under construction, there is still insufficient elaboration on its meaning, which justifies it is always mentioned together with disease prevention in discourses.

The main pedagogical strategies functioning as devices for the development of competencies for health promotion are contextualized learning by considering the complexity of the social reality, and students' insertion and immersion in reality.

The most favorable contexts to reflective practice in the development of competencies for health promotion are those including the teaching-service-community integration and teacher-student interaction. These curricular strategies can break with the social matrix of reproductive, normative and conventional character and stimulate the innovative and creative character. The Practice of
Teaching-Service-Community Integration (PIESC) brings together these different strategies and is presented as the hallmark of the Course in the development of competencies for health promotion.

The contradictions demonstrated in the study are related to spaces and moments in which the development of competencies for health promotion are revealed, and allow the problematization of the integration and reflective practice proposed in the CPP. The experience in the pedagogical process shows innovations in strategies and activities of teaching, but, also reveals challenges for the consolidation of a curriculum that transforms the current teaching model.

The findings of this study reinforce that doing Nursing is only taught with immersion in practice. With this, we advocate in favor of discussions in the national scenario by criticizing the proposal of professional training entirely by distance learning (DL).

\section{RESUMO}

Objetivo: Analisar a inserção na prática profissional reflexiva como estratégia para o desenvolvimento de competências para a promoção da saúde na formação do enfermeiro. Método: Estudo de caso, de abordagem qualitativa, ancorado no referencial teórico-metodológico da dialética marxista. Os dados foram obtidos de documentos, entrevistas com egressos e grupos focais com docentes de uma instituição de ensino superior em Enfermagem, de Minas Gerais, Brasil, e submetidos à análise crítica de discurso. Resultados: Os contextos mais favoráveis à prática reflexiva no desenvolvimento das competências para a promoção da saúde são os que comportam a prática da integração ensinoserviço-comunidade, interação professor-estudante e trabalho em equipe. $\mathrm{O}$ discurso da inserção precoce encontra-se hegemonicamente construído como prática social do cenário do estudo. Conclusão: A proposta curricular do cenário do estudo tem características que favorecem o aprender a fazer mediado pela experiência e reflexividade, mobilizando o desenvolvimento de competências para a promoção da saúde. Para além da inserção, a imersão do estudante na realidade dos serviços gera experiências num processo reflexivo-crítico.

\section{DESCRITORES}

Educação em Enfermagem; Promoção da Saúde; Educação Baseada em Competências; Currículo.

\section{RESUMEN}

Objetivo: Analizar la inserción en la práctica profesional reflexiva como estrategia para el desarrollo de competencias para la promoción de la salud en la formación del enfermero. Método: Estudio de caso, de abordaje cualitativo, anclado en el marco de referencia teórico metodológico de la dialéctica marxista. Los datos fueron obtenidos de documentos, entrevistas con licenciados y grupos focales con docentes de un centro de educación superior en Enfermería, de Minas Gerais, Brasil, y sometidos al análisis crítico de discurso. Resultados: Los contextos más favorables a la práctica reflexiva en el desarrollo de las competencias para la promoción de la salud son los que comportan la práctica de la integración enseñanza-comunidad, interacción profesor-estudiante y trabajo en equipo. El discurso de la inserción precoz se halla hegemónicamente construido como práctica social del escenario del estudio. Conclusión: La propuesta curricular del escenario de estudio tiene características que favorecen el aprender a hacer mediado por la experiencia y reflexividad, movilizando el desarrollo de competencias para la promoción de la salud. Más allá de la inserción, la inmersión del estudiante en la realidad de los servicios genera experiencias en un proceso reflexivo crítico.

\section{DESCRIPTORES}

Educación en Enfermería; Promoción de la Salud; Educación Basada en Competencias; Curriculum.

\section{REFERENCES}

1. World Health Organization. The Ottawa Charter for Health Promotion. First International Conference on Health Promotion [Internet]. Ottawa, Canada: WHO; 1986 [cited 2017 Aug 17]. Available from: http://www.who.int/healthpromotion/conferences/previous/ottawa/en/

2. Silva KL, Araújo FL, Santos FBO, Andrade AM, Basílio NC, Sena RR. O que vem se falando por aí em competências no ensino da promoção da saúde na formação do enfermeiro? ABCS Health Sci. 2015;40(3):286-93.

3. Netto L, Silva KL, Rua MS. Reflective practice and vocational training: theoretical approaches in the field of health and nursing. Esc Anna Nery. 2018;22(1):e20170309. DOI: http://dx.doi.org/10.1590/2177-9465-ean-2017-0309

4. Dalla-Lana L, Arend-Birner J. Un relato de caso sobre construcción y preparación del portafolio como metodología evaluativa de aprendizaje. Cienc Enferm. 2015;21(3):101-12.

5. Schön DA. Educando o profissional reflexivo: um novo design para o ensino e a aprendizagem. Porto Alegre: Artmed; 2000.

6. Hentges A. Ressignificando a atuação da supervisão pedagógica na educação básica. Rev Multidiscipl Educ. 2017;4(7):59-77.

7. Iijima DW, Szymanski MLS. Relações entre rotinas em sala de aula e dificuldades de aprendizagem. Educ Unisinos. 2015;19(2):261-72.

8. Carvalho VL, Oliveira ALC, Alves IKS, Silva RL, Silva CB. Competências para promoção da saúde em formandos dos cursos da área da saúde. Rev Enferm UFPE On Line [Internet]. 2017 [citado 2017 ago. 12];11 Supl.8:326-78. Disponível em: https://periodicos.ufpe.br/ revistas/revistaenfermagem/article/view/110193/22082 
9. Pinheiro DGM, Scabar TG, Maeda ST, Fracolli LA, Pelicioni MCF, Chiesa AM. Competências em promoção da saúde: desafios da formação. Saúde Soc. 2015;24(1):180-8.

10. Barry MM, Battel-Kirk B, Davison H, Dempsey C, Parish R, Schipperen M, et al. The CompHP project handbooks. Paris: International Union for Health Promotion and Education; 2012.

11. Minayo MCS. Pesquisa social: teoria, método e criatividade. 34ta ed. Petrópolis: Vozes; 2015.

12. Guimarães EAA, Rennó HMS, Rates HF, Ricas J, Souza MCC, Oliveira VC, et al. Projeto Pedagógico do Curso de Enfermagem. Divinópolis: UFS]; 2009.

13. Fairclough N, Melo IF. Critical discourse analysis as a method in social scientific research. Linha D'Água. 2012;25(2):307-29.

14. Souza DN, Souza FN. Aplicação de software na investigação qualitativa. Rev Gaúcha Enferm [Internet]. 2016 [citado 2017 ago. 17];37(3). Disponível em: http://www.seer.ufrgs.br/index.php/RevistaGauchadeEnfermagem/article/view/67901/38764

15. Tong A, Sainsbury P, Craig J. Consolidated criteria for reporting qualitative research (COREQ): a 32-item checklist for interviews and focus groups. Int J Qual Heal Care. 2007;19(6):349-57.

16. Carvalho FFB, Cohen SC, Akerman M. Reflecting on the established in Health Promotion to problematize "dogmas". Saúde Debate. 2017; 41(n.spe3):265-76.

17. Anjos DRL, Aguilar-da-Silva RH. Questionário de Vivências Acadêmicas (QVA-R): avaliação de estudantes de medicina em um curso com currículo inovador. Avaliação (Campinas). 2017;22(1):105-23.

18. Crecci VM, Fiorentini D, Crecci VM, Fiorentini D. Professional development within teacher learning communities. Educ Rev (Belo Horizonte) [Internet]. 2018 [cited 2018 Mar 22];34:e172761. Available from: http://www.scielo.br/pdf/edur/v34/en_1982-6621-edur34-e172761.pdf

19. Grzybowski LS, Levandowski DC, Costa ELN. O que aprendi com o PET? Repercussões da inserção no SUS para a formação profissional. Rev Bras Educ Med. 2017;41(4):505-14.

20. Alves NG. Formação de docentes e currículos para além da resistência. Rev Bras Educ. 2017;22(71):e227147.

21. Kawakame PMG, Miyadahira AMK. Assessment of the teaching-learning process in students of the health area: cardiopulmonary resuscitation maneuvers. Rev Esc Enferm USP. 2015;49(4):652-58. DOI: http://dx.doi.org/10.1590/S0080-623420150000400017

Conselho Nacional de Desenvolvimento Científico e Tecnológico - CNPq. Process number: 204340/2014-4. 